\title{
Cross-Cultural Conflict in A Multinational Company (Case of Japanese Company in Indonesia)
}

\author{
Devita Eka Santi \\ Communication Department \\ Universitas Indonesia \\ Jakarta, Indonesia \\ devitaes@gmail.com
}

\begin{abstract}
In the growth of global business, there are many multinational companies developing their business in Jakarta, one of them are Japanese companies. Multinational companies is an increasingly widespread phenomenom. Companies now more exposed to different cultures between workers. In this paper, the case of PT Hanwa Indonesia, a Japanese multinational company with operations in Indonesia. Based on qualitative interviews with Japanese and Indonesian workers, the study demonstrates the differences of two cultures within one company from Geert Hofstede's cultural dimensions: power distance, individualism/collectivism, masculinity/femininity, uncertainty avoidance, long and short term orientation.
\end{abstract}

Keywords - culture, multinational company, Hofstede's cultural dimensions, intercultural

\section{INTRODUCTION}

In the growth of global business, there are many multinational companies developing their business in Jakarta, one of them are Japanese companies. With the existing of multinational companies in Jakarta, there is a process of communication between two or more cultures within a company. In this case, Indonesian and Japanese culture meets within one company. These days, Japanese multinational companies have accelerated their entry into and capture of emerging markets. Japanese companies had been pioneers in leveraging emerging countries advantages in manufacturing, they have suffered from poor market success in emerging countries [1].

Cultures has a big impact on many factors including developed within the international business field to become a focal issue and management style. In particular, the knowledge of Indonesian and Japanese influence on organizational management. [2]

Nowadays, more Japanese companies are choosing Indonesia to invest. Japanese culture is quite different from Indonesia culture. Japanese culture is rich and diverse. Japan possesses a long and rich cultural history although many of the basic elements originated abroad, especially in China. Employees in Japan are generally known for their loyalty to their places of work and for having clear ambitions to see the companies they work for succeed and prosper [3]. Furthermore, according to a study of Wolf and Gan (2013) management style in Japan usually does not empower managers as an exclusive source of information, which is responsible for solving any problems in the company. Each employee is invited to share their opinions and ideas and take part in improving the company's management and production.
Managers who take others and expect everyone to contribute knowledge to the company. [3].

While in Indonesia, the characteristics of the patriarchal leadership style in which Indonesia has a fatherly role is expected to behave wisely and honestly. This argument is based on the fundamental roots of Javanese culture. The role of women in Indonesia nowadays is the result of a complex mix of traditional Indonesian traditions, Islamic law, and more recent socio-political developments [4].

One of the multinational companies that do business in Jakarta, PT Hanwa Indonesia, is a Japanese company that operates in Indonesia. According to the Japanese Ambassador, Masafumi Ishi, by 2018 there were around 1,500 Japanese companies in Indonesia. Japan itself contribution reached US\$ 52.5 billion to the GDP produced formally [5].PT Hanwa Indonesia is a company that develops international business where it trades a variety of materials for the Indonesian and international markets (import and export) in the field of steel products, construction materials, non-ferrous metals, recycle materials, chemicals, food, wood, construction and engineering as well as research and development.

Intercultural encounters of the two cultures in one company can lead to conflict between Japanese and Indonesia workers. If not managed properly, conflicts can cause bad feelings, expensive litigation, high costs, and challenges that will be difficult for members of the company [6].

In PT Hanwa Indonesia, it is very closely related to differences in intercultural management interaction. Decision making, project planning, meetings, giving feedback to staff members are examples of universal management activites but they all become more challenging when managers work across corporate cultural boundaries. Within the company, the communication process can run with the flow, pattern, and direction of information within the organization. Within multinational companies, there is intercultural communication and how information is conveyed so company operations can run well [7].

\section{RESEARCH METHOD}

From this paper, the method used is descriptive qualitative. Descriptive method is a method in examining the status of a group of people, a set of conditions, and object, or a class of events in the current period. Descriptive method is a method for finding facts through proper interpretation [8]. The data have been drawn from in depth interview, observation, and literature studies. Primary data were obtained by in-depth 
interviews with two informants through a purposive sample technique, Marketing Director with Japanese citizenship and Manager with Indonesia citizenship. As for secondary data, the authors obtained through journals, books, and previous research literature studies.

The paradigm used in this paper is interpretative paradigm. According to Snape and Spencer, the interpretative paradigm in general had emerged in the 1970s as a reaction to positivism which was the dominant paradigm in social science at that time. In the interpretative paradigm has several distinguishing features. The interpretative aspect means that the approach seeks to understand people's life experiences from the perspective of the person itself, which is often referred to as an emic perspective or an indiser's perspective [9]

In this paper, the objective is to understand the experience of work culture between Japanese and Indonesia within multionational company, PT Hanwa Indonesia, by looking from intercultural interactions by Japanese management and local employees through the international business work system. This study investigates the differences between Japanese and Indonesian workers working culture in a Japanese company in Indonesia. The existence of cultural differences between Japan and Indonesia seen from Hofstede's Cultural Dimensions divided by dimensions of individualis-collcetivism (IC), masculinity-femininity (MF), power distance (PD), and avoidance of uncertainty or unvertainty avoidance (UA), long-term orientation or short term orientation [10].

\section{RESULT AND DISCUSSION}

This research took a sample of 78 respondents consist of pre-elderly and elderly who live in Sidoarjo District. The Indonesian government has set the age limit for the pre-elderly group (45 - 59 years) and the elderly group (60 years and over).

Culture as part of social interaction in life has a deep relation to factors of culture such as symbolism, family interaction, values, language, and in the countries where we are. All cultural factors can be linked together. Understanding corporate culture is assessing what is shared by individuals in organization, their beliefs, values, attitudes, and norms of behavior. Organizational culture includes the shared meanings that individuals place in their work lives and the narratives they use to understand their organizational context. To make acceptable and legitimate organizational rules; people need understanding, and the ability to describe and understand the context of their work; rules act as a kind of social and normative [4].

Hofstede (1980) was the first researcher to reduce cross-national cultural diversity into state scores on a number of dimensions. Hofstede built his cultural framework from data collected in attitude surveys conducted at IBM subsidiaries in 72 countries between 1968 and 1973[11].

Dimensions of culture used to measure cultural differences. In order to identify the basic difference between national culture, Hofstede created four dimensions - power distance, uncertainty avoidance, individualis - collectivism, masculinity - femininity. Later, extended by a fifth, long-term versus short-term orientation. Each dimension represents a different continuum [12].
Power distance measures "how far the less powerful members of companies within a country can accept that power distributed unequally" as Hofstede said. Is supervisor right because they are supervisor (large/high power distance) or only because supervisor knows the correct answer (small/low power distance) [12].

Based on Hofstede study, power distance for Indonesia is large with score 78 while power distance in Japan is small with score 54. In the large power distance situation, usually superiors and subordinates consider each other as existentially unequal and the hierarchical system is based on this existential inequality. Relationships between subordinates and superiors in a large-power-distance company usually frequently loaded with emotions. A country like Indonesia is distinguished by high power distance when leader may play a role in certain ways. Meanwhile, for small power distance like Japan with score 54, subordinates and superiors consider each other as existentially equal, roles may be changed, the hierarchical system is just an inequality of roles, someone who today is my subordinate may tomorrow be my boss kinda role. Small power distance usually created a company with fairly decentralized with flat hierarchical pyramids and limited numbers of supervisory personnel [13]. In PT Hanwa Indonesia itself, for Indonesian staff, employees waiting for direction from superiors for every assignment given. While for Japanese management in PT Hanwa Indonesia, they expected their Indonesia employees to do work on their own initiative. Japanese management used to having employees with high initiative, they don't want to give continuous directions. Indonesia employees expect to be told what to do for every task. At PT Hanwa Indonesia, they are several Indonesia managers whose expected to be able to implement a work culture like Japanese. Indonesia managers should work without detail instructions from Japanese management

Uncertainty avoidance measures how far the members of a culture feel threatened by unknown situations. Uncertainty avoidance indicates how far a society feels threatened by ambiguous situations and how society tries to avoid these situations by adopting strict codes of a belief in the absolute truths, not tolerating deviant ideas, and establishing formal rules. Usually individuals with high uncertainty avoidance very concerned with security in life, tend to avoid to take a risk while individuals in low uncertainy avoidance societies are less concerned with security and they are more risk tolerant [12]. Uncertainty avoidance in Indonesia is quite low with score 48 while in Japan is high with score 92 . For Indonesia employees with low uncertainty avoidance score, they believe there shoul be no more rules than are necessary and if they are ambiguous or do not work, they should be changed. Usually Indonesia company can apply flexible schedules but not for PT. Hanwa Indonesia. Schedules and working hour cannot be flexible, tap in at 08.30 and tap out at 17.30. if the employee is late then the salary will be deducted. Usually punctuality and precision do not come naturally for Indonesia employees, but as long as they work at PT Hanwa Indonesia, punctuality is a must.

Hofstede (2005) explained regarding avoid uncertainty, in dealing with Indonesian, a case like expatriates employees like Japan who come from countries with strong uncertainty avoidance, working in the Indonesian business environment make them have to respect the behavior of the major ethnicity who work with them, which is characterized by weak 
uncertainty avoidance such as culture work slowly and with less initiative, it turns out may frustrate the Japanese [4]. Working with two cultures within one company, requires Japanese managers at PT Hanwa Indonesia to adapt to the work culture of Indonesian employees while they also still indicate them Japanese work culture.

Individualism/collectivism considered as two opposite poles in cultural dimension scale. Hofstede $(1990,2002)$ explained individualism as pertains to societies in which the ties between individuals are loose. Everyone is expected to look after himself or herself and his or her immediate family. While for collectivism, people from birth onward are cohesive in-groups, integrated into strong, which throughout people's lifetime continue to protect them in exchange for unquestioning loyalty [6]. For individualism, Japan has high individualism with score 46 while Indonesia has low individualism so Indonesia considered as collectivism with score level 14. Indonesia is a collectivism society with type long-term commitment to the member group, extended family or extended relationship. Employee relationships are perceived in moral terms and promotion or hiring take account of the employee's in group. Employed persons in Japanese company with high individualist culture are expected to act according to their own interest and work should organized in such a way that this self-interest and the employer's interest coincide. At PT Hanwa Indonesia, only employee with employee basically moral like family interaction. For employer (Japanese management) and Indonesian workers, the relationship is individually, everyone is expected to look after themselves.

Masculinity shows a cultural preference for heroism, achievement, assertiveness, and material success. For femininity represents a preference for modesty, caring for the weak, relationship, and quality of life based from Hofstede explanation (1984). A high score for masculinity indicates that the society will be driven by competition, success and achievement, with success being defined by the best in field. A low score (feminine) means that the dominant values in society are caring for others and quality of life. A feminine society is one where quality of life is the sign of success and standing out from the crowd is not admirable [6]. Masculinity in indonesia is low with score 48 while in Japan is high with score 95. Japanese management at PT Hanwa Indonesia will be driven by competition, very focus for achievement and success, and very profit oriented. They always. Japanese management always want to compete, see every achievement gained by competitors, and always want to be ahead of the competitors. Japanese management live in order to work, competition, and performance. They want to solve every conflict.

Hofstede and Michael Bond from Chinese University of Hong Kong did Chinese Value Survey and discovered new dimension called long and short-term orientation. Long term orientation stands for the stering of virtues oriented toward future rewards-in particular, perseverance and thrift. Meanwhile, short term orientation stands for the fostering of virtues related to the past and present, respect for tradition, fulfilling social obligation, and preservation of face based on Hofstede explanation (2002).

\section{CONCLUSION}

The purpose of the present study was to learn how to see the differences of work culture between Japanese and Indonesian within a Japanese company in Indonesia. From Geert Hofstede cultural dimension, there are power distance, uncertainty avoidance, individualism/collectivism, masculinity/femininity, and long and short term orientation.

Based on Hofstede cultural dimension, the are differences between Japanese and Indonesian work culture. Expatriate managers, in this case, Japanese managers, working in Indonesia can take advantage of having knowledge of cultural values from Indonesian values in the workplace. They have an opportunity to gain insight into Indonesians values which considered necessary to create for best leadership style to be effectively implemented in Indonesia. Japanese management at PT Hanwa Indonesia is a highly structured society. With Indonesian work culture, they need to adapt with how Indonesian cannot be as punctual as them, and not as loyal as them.

\section{REFERENCES}

[1] K. Nakagawa, M. Nakagawa, H. Fukuchi, M. Sasaki, and K. Tada, "Japanese Management Styles: to Change or Not to Change? A Subsidiary Control Perspective," vol. 6, no. 2, pp. 1-10, 2018.

[2] M. Huettinger, "Cultural dimensions in business life: Hofstede' $\mathrm{s}$ indices for Latvia and Lithuania," vol. 3, no. 3, pp. 359-376, 2008.

[3] R. Wolf and R. Gan, "MANAGEMENT RELATIONS IN THE WORK CULTURE IN JAPAN AS COMPARED TO THAT OF THE WEST," pp. 116-122, 2013.

[4] D. W. Irawanto, "An Analysis of National Culture and Leadership Practices in Indonesia," vol. 3, no. 7, pp. 718-724, 2014.

[5] Investor Daily, "1.500 Perusahaan Jepang Beroperasi di Indonesia," Jakarta, 21-Jan-2018.

[6] K. W. Huey, "Cross-Cultural Worker Conflict In a Multinational Company: The Case of Ibiden, A Japanese Company in Malaysia," pp. $1-31,2012$.

[7] H. Kotthoff and H. Spencer-Oatey, Handbook of Intercultural Communication. Bremen: Hubert \& Co., Gottingen, 2007.

[8] F. Whitney, The Elements of Research (Asian Edition). Osaka: Overseas Book Co, 1960.

[9] M. Hennink, I. Hutter, and A. Bailey, Qualitative Research Methods, First Edit. London: Sage Publications, Ltd, 2011.

[10] K. D. Lo and R. D. Waters, "Assessing the Applicability of Hofstede ' s Cultural Dimensions for Global 500 Corporations ' Facebook Profiles and Content," vol. 21, pp. 51-67, 2017.

[11] S. Beugelsdijk and C. Welzel, "Dimensions and Dynamics of National Culture : Synthesizing Hofstede With Inglehart," 2018

[12] N. Podrug and M. Sc, "CROSS-CULTURAL COMPARISON OF HOFSTEDE' S DIMENSIONS AND DECISION-MAKING STYLE WITHIN CEE CONTEXT," pp. 1-16, 1992.

[13] G. Hofstede, G. J. Hofstede, and M. Minkov, Cultures and Organizations. New York: McGraw-Hill, 2010. 